\title{
Substrate specificity and properties of the Escherichia coli 165 rRNA methyltransferase, RsmE
}

\author{
GEORGETA N. BASTUREA and MURRAY P. DEUTSCHER
}

Department of Biochemistry and Molecular Biology, Miller School of Medicine, University of Miami, Miami, Florida 33136, USA

\begin{abstract}
The small ribosome subunit of Escherichia coli contains 10 base-methylated sites distributed in important functional regions. At present, seven enzymes responsible for methylation of eight bases are known, but most of them have not been well characterized. One of these enzymes, RsmE, was recently identified and shown to specifically methylate U1498. Here we describe the enzymatic properties and substrate specificity of RsmE. The enzyme forms dimers in solution and is most active in the presence of 10-15 $\mathrm{mM} \mathrm{Mg}^{2+}$ and $100 \mathrm{mM} \mathrm{NH}_{4} \mathrm{Cl}$ at $\mathrm{pH} 7-9$; however, in the presence of spermidine, $\mathrm{Mg}^{2+}$ is not required for activity. While small ribosome subunits obtained from an RsmE deletion strain can be methylated by purified RsmE, neither $70 S$ ribosomes nor $50 S$ subunits are active. Likewise, 16S rRNA obtained from the mutant strain, synthetic 16S rRNA, and 3' minor domain RNA are all very poor or inactive as substrates. $30 \mathrm{~S}$ particles partially depleted of proteins by treatment with high concentrations of $\mathrm{LiCl}$ or in vitro reconstituted intermediate particles also show little or no methyl acceptor activity. Based on these data, we conclude that RsmE requires a highly structured ribonucleoprotein particle as a substrate for methylation, and that methylation events in the $3^{\prime}$ minor domain of $16 S$ rRNA probably occur late during $30 S$ ribosome assembly.
\end{abstract}

Keywords: E. coli; methyltransferase; RNA modification; small subunit

\section{INTRODUCTION}

Ribosomes are large ribonucleoprotein particles that play a central role in genetic information decoding and protein synthesis. In order to perform their complex functions, proper assembly of all their constituent components is necessary. Maturation into functional ribosomes requires, in addition to RNA processing, a series of nucleotide modification events at the level of ribosomal RNA. Three main types of nucleotide modification are known: pseudouridine formation by uridine isomerization, 2'-hydroxyl ribose methylation, and base methylation.

In prokaryotes, the most common modification in rRNA is base methylation. Although these modifications are not essential for protein synthesis in vitro (Cunningham et al. 1991), their localization and conservation suggest that they might be important for folding, assembly, or stability of ribosomes in vivo. All the methyl groups in rRNA are added by site-specific methyltransferases, but

Reprint requests to: Murray P. Deutscher, Department of Biochemistry and Molecular Biology, Miller School of Medicine, University of Miami, P.O. Box 016129, Miami, FL 33101-6129, USA; e-mail: mdeutsch@ med.miami.edu; fax: (305) 243-3955.

Article published online ahead of print. Article and publication date are at http://www.rnajournal.org/cgi/doi/10.1261/rna.700507. relatively little is known about these enzymes or their mechanisms of action.

Ten base-methylated residues are present in the small subunit rRNA of Escherichia coli, all of which are distributed in important functional regions: the tRNA binding sites, the decoding region, and the mRNA binding area. At present, seven enzymes responsible for modification of eight bases are known. These include $k s g A$, which encodes RsmA, the methyltransferase responsible for methylation at both $\mathrm{A} 1518$ and $\mathrm{A} 1519, \operatorname{rsmB}$ and $r s m C$, which code for the two enzymes that produce $\mathrm{m}^{5} \mathrm{C} 967$ and $\mathrm{m}^{2} \mathrm{G} 1207$, respectively (Ofengand and Del Campo 2004), and $r s m D$, rsmE, $r s m F$, and $r s m G$, previously named $y h h F, y g g J, y e b U$, and $\operatorname{gid} B$, recently identified as the genes encoding enzymes responsible for the $\mathrm{m}^{2} \mathrm{G} 966$ (Lesnyak et al. 2007), $\mathrm{m}^{3} \mathrm{U} 1498$ (Basturea et al. 2006), $\mathrm{m}^{5} \mathrm{C} 1407$ (Andersen and Douthwaite 2006), and $\mathrm{m}^{7} \mathrm{G} 527$ (Okamoto et al. 2007) modifications in $16 \mathrm{~S}$ rRNA. To date, most of these enzymes have not been studied in detail.

The U1498 methylation is localized in a conserved region of $16 \mathrm{~S}$ rRNA, the $3^{\prime}$ minor domain of the small ribosomal subunit. This region is part of the ribosome's decoding domain and is known to be important for aminoacyl-tRNA selection and protein synthesis in vitro (Cunningham et al. 1991). However, its role in protein synthesis in vivo is 
unclear. It has been suggested that $\mathrm{m}^{3} \mathrm{U} 1498$ might have a role in intersubunit communication based on its localization at the top of helix 44, a region involved in interactions with the large ribosomal subunit (Decatur and Fournier 2002). Most recently, it was shown that U1498 directly interacts with the ribose-phosphate backbone of the codon region (Berk et al. 2006; Korostelev et al. 2006), and that it is involved in the formation of an electronegative pocket that might bind free nucleotides under certain conditions (Berk et al. 2006). Cells lacking the modification at U1498 appear to grow normally, but they cannot compete when grown together with wild-type cells (Basturea et al. 2006), suggesting that methylation at this position has a subtle, but important, role in cell physiology.

RsmE, the $\mathrm{m}^{3} \mathrm{U} 1498$ specific methyltransferase, was identified by analysis of several putative methyltransferase deletion strains, and was confirmed by gene complementation, overexpression, and determination of the in vitro activity of the purified recombinant enzyme (Basturea et al. 2006). The enzyme has high specificity for U1498 and is not involved in methylation of the only other $\mathrm{m}^{3} \mathrm{U}$ site in the E. coli ribosome, position 1915 in 23S rRNA (Basturea et al. 2006). Although RsmE shares the knot structure characteristic of SPOUT methyltransferases (Forouhar et al. 2003), the protein defines a new family of methyltransferases characterized by its own specific motifs (Basturea et al. 2006). On this basis, it was suggested that other members of this family are also base methyltransferases (Basturea et al. 2006). In view of the widespread distribution of this protein, and U1498 methylation among bacteria and plants, additional study of this enzyme was deemed important. In this paper, we describe the physical and enzymatic properties of purified RsmE. Most importantly, we show that activity is dependent on a fully assembled 30S ribosome subunit. 16S rRNA and subunits devoid of only a few ribosomal proteins are either inactive or only poorly active as substrates. This study, which provides a detailed examination of RsmE, is the first characterization of a member of this new methyltransferase family.

\section{RESULTS}

\section{His-RsmE is active in vivo}

We previously cloned, expressed, and purified His-tagged RsmE (Basturea et al. 2006) and showed that it has $\mathrm{m}^{3} \mathrm{U} 1498$-specific methyltransferase activity in vitro. Since many of the experiments described here were performed with the His-tagged enzyme, it was of interest to ascertain whether the His-tagged protein actually functions in vivo. For this purpose, gene complementation was used to evaluate the ability of His-RsmE to methylate U1498. The rsmE gene region was cloned into pET32a such that the protein would be expressed either in its native form
(pET32a-rsmE) or with an N-terminal His-tag identical to the one used for protein purification (pET32a-HisrsmE). Strain MG1655 rsmE::kan was transformed with either the empty pET32a vector or with the $r s m E$-containing plasmids, and grown to the exponential phase. Total cellular RNA was extracted from the transformed strains, as described (Ofengand et al. 2001), and equal amounts were tested for the presence of U1498 methylation by primer extension analysis (Basturea et al. 2006). Complementation with the low copy number vector pHC79 and pHC79rsmE, described previously (Basturea et al. 2006), was also included as additional controls.

As shown in Figure 1, methylation at U1498 could be restored when the rsmE mutant strain was transformed with either pHC79-rsmE, pET32a-rsmE, or pET32a-HisrsmE (Fig. 1, lanes 5,7,8). In contrast, no restoration was observed with RNA extracted from cells transformed with the empty vectors, pHC79 and pET32a (Fig. 1, lanes 4,6). It should be noted that, while RsmE expression is under control of its own promoter in cells transformed with pHC79-rsmE (Basturea et al. 2006), expression from both pET32a-rsmE and pET32a-His-rsmE is under control of an IPTG inducible T7 promoter. However, U1498 was still methylated in cells transformed with either of these two plasmids even though the cells lack T7 RNA polymerase, most likely due to the presence of an RsmE promoter-like region in the plasmid. Nevertheless, the data presented indicate that in vivo methylation of U1498 was not altered by the presence of an N-terminal His-tag on RsmE and,

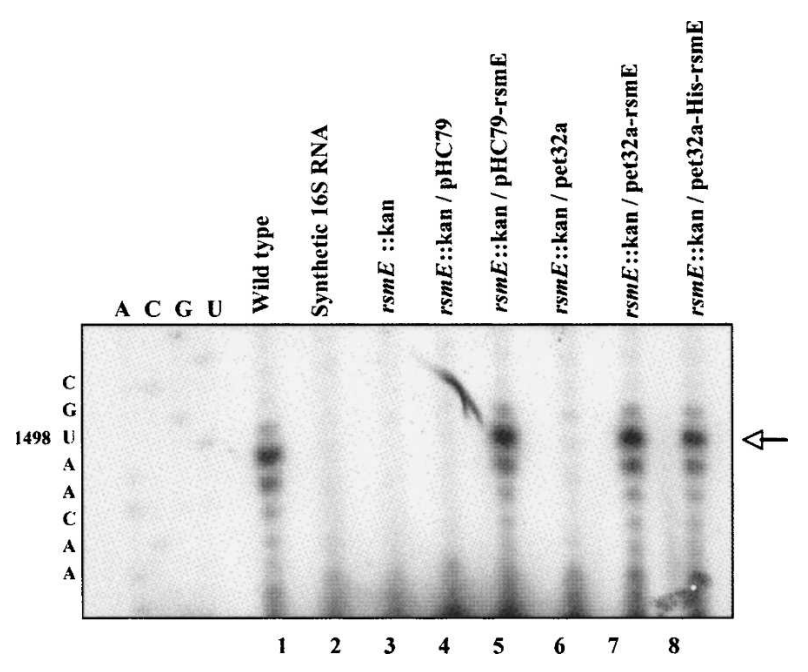

FIGURE 1. Primer extension analysis of total cellular RNA. Extracted RNA was annealed to a $\left[{ }^{32} \mathrm{P}\right]$-labeled primer complementary to residues 1506-1525 in 16S rRNA, prior to extension by M-MLV-RT as described in Materials and Methods. Products of the reaction were separated on $8 \%$ polyacrylamide/7 $\mathrm{M}$ urea denaturing gels and visualized by autoradiography. A stop at position A1499, noted by the arrow, indicates the presence of a methyl group at U1498. Data similar to those in lanes 1-5 were reported previously (Basturea et al. 2006). They were repeated for this experiment and are included as controls. 
therefore, that analysis of the tagged enzyme should provide valid information about its properties. Moreover, subsequent purification of nontagged RsmE revealed that His-RsmE is approximately two-thirds as active as the native enzyme in vitro, indicating that the presence of the His-tag has, at most, only a small effect on the enzyme's activity (data not shown).

\section{Physical proprieties of RsmE and His-RsmE}

Crystal structures of RsmE family proteins from Haemophilus influenzae (YggJ, PDB entry 1NXZ; Forouhar et al. 2003), Bacillus subtilis (YqeU, PDB entry 1VHK; Badger et al. 2005), Thermotoga maritima (Tm1380, PDB entry 1Z85; http://www.rcsb.org/pdb/), and Thermus thermophilus (Tt1573, PDB entry 1V6Z; Joint Center for Structural Genomics, http://www.rcsb.org/pdb/) have been determined, and indicated that RsmE forms dimers in the crystals. To determine the actual oligomeric state of the E. coli protein in solution, we analyzed purified His-RsmE by gel filtration chromatography on a Superose- 6 column. The enzyme eluted as a single peak at a retention volume corresponding to a molecular mass of $\sim 50 \mathrm{kDa}$, close to the expected size for a His-RsmE dimer of $\sim 54 \mathrm{kDa}$, assuming it is a globular protein. Nontagged RsmE also eluted at a retention volume corresponding to a dimer (data not shown), supporting the conclusion that RsmE is a dimer in solution as well.

Purified His-tagged RsmE had an $\mathrm{A}_{280} / \mathrm{A}_{260}$ ratio of 1.5, somewhat lower than the theoretical value of 1.7 calculated from its amino acid composition (Gill and von Hippel 1989). This difference is likely due to the presence of some protein-bound SAM in the protein preparation. Based on the observed $\mathrm{A}_{280} / \mathrm{A}_{260}$ ratio, $\sim 10 \%$ of the His-RsmE molecules appear to retain SAM or S-adenosyl-homocysteine (SAH) during purification. Even more dramatic, the absorption spectrum of the purified, nontagged protein peaked at $260 \mathrm{~nm}$, which is unusual for pure proteins (data not shown). The $A_{280} / A_{260}$ value for this preparation was 0.55 , very close to the 0.6 value calculated for a $1: 1 \mathrm{RsmE}-$ adenosine complex, suggesting that untagged RsmE binds SAM with high affinity. This is not unexpected as other methyltransferases also were found to bind the SAM cofactor so tightly that it was retained during purification. One example of a well-characterized enzyme is the RNA methyltransferase, RrmJ (Hager et al. 2002).

\section{In vitro activity of RsmE}

As a prelude to examining the substrate specificity of RsmE, we first determined its optimal reaction conditions. Assays were carried out using as substrate $30 \mathrm{~S}$ particles derived from the rsmE mutant strain and purified HisRsmE. Optimal activity was observed at pH 7-9 (data not shown). Since $\mathrm{NH}_{4}{ }^{+}$and $\mathrm{Mg}^{2+}$ are known to affect rRNA methyltransferase activities, we also examined their effect on the activity of RsmE. Maximal activity was obtained at $100 \mathrm{mM} \mathrm{NH}{ }_{4} \mathrm{Cl}$; higher salt concentrations were strongly inhibitory (data not shown). $\mathrm{A} \mathrm{Mg}^{2+}$ concentration of $10-15 \mathrm{mM}$ resulted in optimal RsmE activity; at $30 \mathrm{mM}$ activity was reduced by $60 \%$. Inasmuch as $\mathrm{Mg}^{2+}$ may be required for maintaining the overall structure of the ribosome substrate, rather than for catalysis per se, we also examined methylation of $30 \mathrm{~S}$ particles depleted of $\mathrm{Mg}^{2+}$ by preincubation with EDTA, but supplemented with the polyamine spermidine (Fig. 2). As shown, EDTA at $10 \mathrm{mM}$ was totally inhibitory, but the activity could be restored up to $\sim 60 \%$ of that with $\mathrm{Mg}^{2+}$ by addition of spermidine at $30 \mathrm{mM}$. These data suggest that $\mathrm{Mg}^{2+}$ is required for maintaining the structure of the $30 \mathrm{~S}$ particle substrate, and that it is not directly involved in catalysis. RsmB, a methyltransferase that modifies free $16 \mathrm{~S}$ rRNA, is known to act in the absence of $\mathrm{Mg}^{2+}$ (Tscherne et al. 1999), but this is the first report that spermidine can substitute for $\mathrm{Mg}^{2+}$ for methyltransferase catalysis.

To further characterize RsmE, we determined apparent $\mathrm{K}_{\mathrm{M}}$ and $\mathrm{k}_{\mathrm{cat}}$ values for the $30 \mathrm{~S}$ ribosome subunit and SAM as described in Materials and Methods. For the ribosome subunit, initial rates were determined at a high concentration of SAM $(100 \mu \mathrm{M})$ and varying concentrations of the 30 S subunit, such that $<20 \%$ of the substrate was used in the reaction. The apparent $\mathrm{K}_{\mathrm{M}}$ value determined under these conditions was $2.0 \pm 0.1 \mu \mathrm{M}$ and the $\mathrm{k}_{\text {cat }}$ was $0.078 \pm 0.006 \mathrm{~min}^{-1}$. To determine the apparent $\mathrm{K}_{\mathrm{M}}$ for SAM, 30S subunits were present at $2.5 \mu \mathrm{M}$ and the SAM concentration was varied (due to substrate limitations it was not possible to exceed $2.5 \mu \mathrm{M}$ for $30 \mathrm{~S}$ subunits).

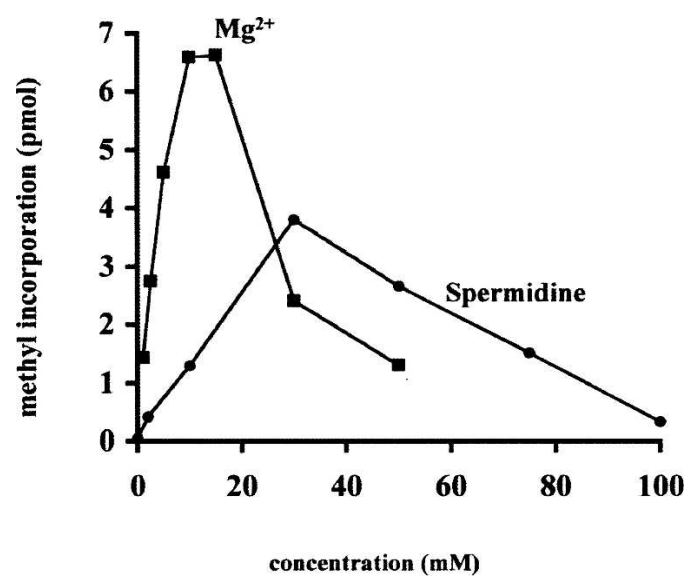

FIGURE 2. Effect of $\mathrm{Mg}^{2+}$ and spermidine on RsmE activity. Ribosome particles $(0.5 \mu \mathrm{M})$ were methylated with $\left[{ }^{3} \mathrm{H}\right]$-SAM $(100$ $\mu \mathrm{M})$ and purified His-RsmE (165 nM), as described in Materials and Methods. The amount of $\left[{ }^{3} \mathrm{H}\right]$-methyl groups incorporated was monitored by acid precipitation and scintillation counting. One experiment representative of three repeats is shown. Although optima were identical among the three experiments, absolute incorporation varied due to use of different ribosome preparations. 
The $\mathrm{K}_{\mathrm{M}}$ value determined for SAM was $26.7 \pm 0.4 \mu \mathrm{M}$ and the $\mathrm{k}_{\text {cat }}$ was $0.042 \pm$ $0.006 \mathrm{~min}^{-1}$. Since rRNA methyltransferases have not been extensively characterized, these parameters generally are not available for most other similar enzymes. However, the $K_{M}$ value for the $30 \mathrm{~S}$ subunit determined for RsmE is comparable to a value of $0.7 \pm 0.05 \mu \mathrm{M}$ determined for $50 \mathrm{~S}$ particles with RrmJ (Hager et al. 2004) and a value of 0.69 $\mu \mathrm{M}$ reported for $23 \mathrm{~S}$ rRNA with ErmC methyltransferase (Maravic et al. 2003); likewise, the $K_{M}$ value for SAM for RsmE is almost identical to that reported for $\mathrm{RlmD}(26 \mu \mathrm{M})$ (Agarwalla et al. 2002).

In contrast, the few $\mathrm{k}_{\mathrm{cat}}$ values determined for these enzymes fall into two groups. That reported for RrmJ, 0.064 $\min ^{-1}$ (Hager et al. 2004) is similar to the values for RsmE, whereas other methyltransferases, RsmB and RlmD, have significantly higher turnovers: $2.6 \mathrm{~min}^{-1}$ (Tscherne et al. 1999) and $3.6 \mathrm{~min}^{-1}$ (Agarwalla et al. 2002), respectively. However, these latter enzymes act on free rRNA and may not require highly structured substrates. In contrast, both RsmE and RrmJ require fully assembled ribosomal particles for methylation in vitro (see below), and their $\mathrm{k}_{\text {cat }}$ values are extremely low. It is unlikely that these enzymes act so slowly in vivo, even though the time required for $30 \mathrm{~S}$ subunit maturation in vivo has been reported to be only a few minutes (Lindhal 1975). It is more likely that they work so poorly in vitro because even the best substrates in vitro are different from the ones that are modified during ribosome assembly in vivo. It is also possible that the purified enzymes may have lost a cofactor that enhances their activity in vivo.

\section{Substrate specificity}

Insight into RsmE's substrate specificity is of critical importance for understanding its function and action in vivo. For this purpose, we examined ribosome particles, as well as various RNA species, as possible substrates for RsmE. As shown in Figure 3A, 30S particles extracted from the $r s m E$ deletion strain can be methylated by RsmE in vitro, whereas $70 \mathrm{~S}$ and $50 \mathrm{~S}$ particles are essentially inactive. Similarly, free RNAs display little or no activity. These include synthetic $16 \mathrm{~S}$ rRNA, synthetic 23S rRNA, and synthetic $3^{\prime}$ minor domain fragment (Fig. 3B). The low level of methyl incorporation into 16S rRNA purified from the mutant strain was reproducibly detected, suggesting that the presence of the other modified nucleotides in the $16 \mathrm{~S}$ rRNA extracted from the deletion strain might confer a slightly different structure to the RNA substrate synthesized in vivo compared with that of the in vitro synthesized RNA. The much more dramatic difference, $>10$-fold, seen between $30 \mathrm{~S}$ subunits and free $16 \mathrm{~S}$ rRNA suggests either that ribosomal proteins alter $16 \mathrm{~S}$ rRNA structure or that one or more ribosomal proteins are directly required for the methylation reaction to proceed.

This, of course, raises the question of what might be the minimal number of ribosomal proteins required for RsmE to methylate $16 \mathrm{~S}$ rRNA in vitro. In an attempt to answer this question, we used the procedure of Itoh et al. (1968) to prepare protein-deficient small subunit particles. Such preparations were obtained from mutant 30 S subunits by treatment with increasing concentrations of $\mathrm{LiCl}$ solutions (Fig. 4A), and each was tested for its methyl acceptor activity (Fig. 4B). Particles obtained by treatment with $1 \mathrm{M}$ $\mathrm{LiCl}$, and sedimenting at $\sim 25 \mathrm{~S}$ (Itoh et al. 1968), retained $\sim 40 \%$ of the activity of mock-treated 30 S subunits. However, only a very low level of activity was observed with ribosomes treated with $1.5 \mathrm{M} \mathrm{LiCl}$, and no activity was seen with the smaller particles (Fig. 4B). The reduced activity of the LiCl-treated particles was due to protein loss, and associated structural changes as the $16 \mathrm{~S}$ rRNA appeared to be undamaged when visualized on agarose gels.

We also analyzed a $21 \mathrm{~S}$ intermediate particle prepared by in vitro reconstitution using purified mutant $16 \mathrm{~S}$ rRNA and total 30S ribosomal proteins (Fig. 5A; Denman et al. 1989; Culver 2003). This particle is thought to contain $16 \mathrm{~S}$ rRNA and 15 early binding proteins: S4-S9, S11-S13, and S15-S20 (Culver 2003). The remaining ribosomal proteins do not bind the particle under these in vitro reconstitution conditions. Treatment of these particles with purified RsmE 
$\mathbf{A}$

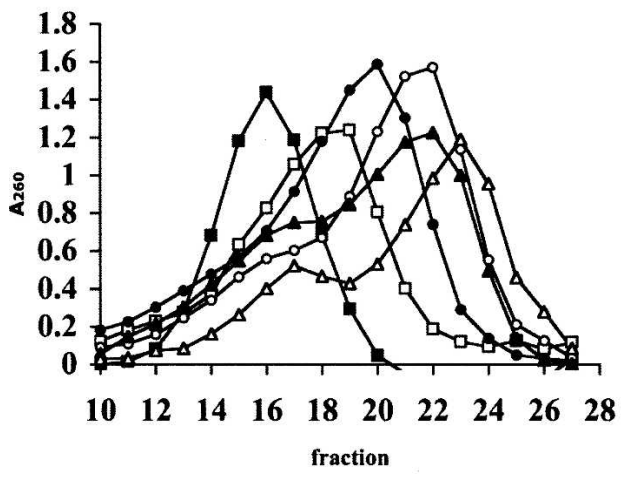

B

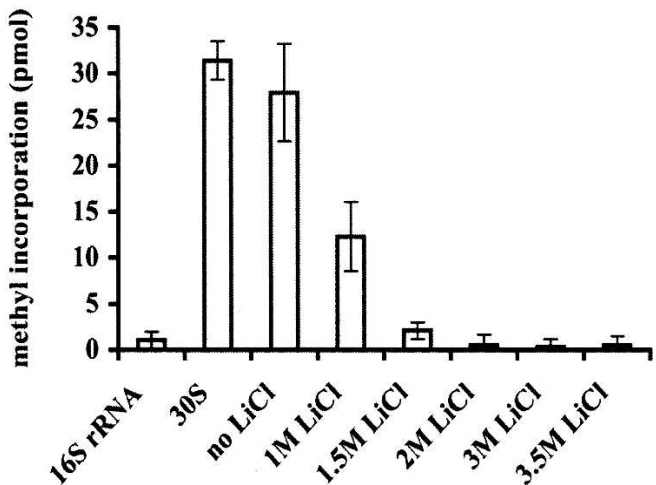

FIGURE 4. RsmE activity on LiCl-washed ribosomal particles. (A) Sucrose gradient profiles of LiCl-washed particles. Mutant $30 \mathrm{~S}$ particles were either mock-treated $(\boldsymbol{\square})$ or treated with $1 \mathrm{M} \mathrm{LiCl}(\square), 1.5 \mathrm{M} \mathrm{LiCl}(\bullet), 2 \mathrm{M} \mathrm{LiCl}(\bigcirc), 3 \mathrm{M} \mathrm{LiCl}(\boldsymbol{\Delta})$, or $3.5 \mathrm{M} \mathrm{LiCl}(\Delta)$ as described in $\mathrm{Materials}$ and Methods, and analyzed on sucrose gradients (top to the right). (B) Activity on LiCl-washed ribosomal particles. 16S RNA, intact 30S subunits, or $30 \mathrm{~S}$ particles $(2 \mu \mathrm{M})$ washed with the indicated concentrations of $\mathrm{LiCl}$ were methylated with $\left[{ }^{3} \mathrm{H}\right]-\mathrm{SAM}(100 \mu \mathrm{M})$ and purified His-RsmE $(165 \mathrm{nM})$ as described in Materials and Methods. The amount of $\left[{ }^{3} \mathrm{H}\right]$-methyl groups incorporated was monitored by acid precipitation and scintillation counting. Data presented are the average of two experiments.

showed that they were only $\sim 15 \%$ as active as intact 30 S particles (Fig. 5B).

Taken together, these data suggest that RsmE must recognize a specific structured form of $16 \mathrm{~S}$ rRNA that is dependent upon the presence of the majority of small subunit ribosomal proteins.

\section{DISCUSSION}

Fully assembled, mature $30 \mathrm{~S}$ ribosomes are the product of a complex process that involves many sequential events including modification of 16S rRNA. Early methylation events probably occur while the RNA is being synthesized, and such methyltransferases must recognize substrates with relatively low structural complexity, whereas those acting at later steps have to recognize more complex substrates containing multiple ribosomal proteins. Many modified nucleotides are located in regions of ribosomal RNA that are buried within the ribosome (Decatur and Fournier 2002). Their localization implies that modifications at these sites take place at stages in which the ribonucleoprotein particles are not fully assembled into ribosomal subunits. In agreement with this idea, some of the known methyltransferases are able to methylate free RNA in vitro and do not act on assembled ribosome particles. These include RsmB, RlmD, and $R \operatorname{lmA}{ }^{\mathrm{I}}$ (Ofengand and Del Campo 2004). Other methyltransferases prefer three experiments. more complex substrates, such as partly structured ribonucleoproteins or completely formed ribosomal subunits. These include RsmC, RrmJ, RsmA (Ofengand and Del Campo 2004), and RsmF (Andersen and Douthwaite 2006).

As shown here, RsmE belongs to the latter group, acting almost exclusively on fully assembled $30 \mathrm{~S}$ particles in vitro. Moreover, it does not methylate $70 \mathrm{~S}$ ribosomes, as might be expected from localization of residue U1498 at the interface between the two ribosome subunits (Yusupov et al. 2001; Schuwirth et al. 2005). Whether the actual in vivo substrate of RsmE is an almost mature 30S subunit is not known. Based on our studies, the best in vitro substrate is the mutant $30 \mathrm{~S}$ particle fully assembled in vivo. However, even
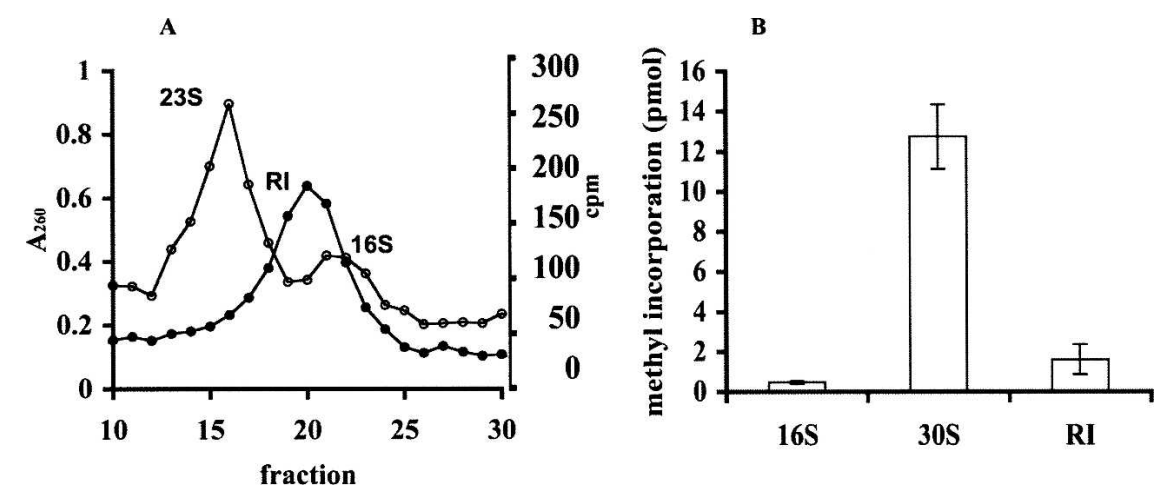

FIGURE 5. RsmE activity of in vitro reconstituted intermediate particles. (A) Sucrose gradient profile of the in vitro reconstitution intermediate (-) (top to the right). In vitro reconstitution reactions were performed as described in Materials and Methods. ${ }^{32} \mathrm{P}$-labeled ribosomal RNAs extracted from $70 \mathrm{~S}$ ribosomes were used as markers $(\mathrm{O})$. (B) Activity of the reconstitution intermediate. 16S RNA, purified natural 30S subunit, or 21S reconstitution intermediate (RI) $(0.5 \mu \mathrm{M})$ were methylated with $\left[{ }^{3} \mathrm{H}\right]$-SAM $(100 \mu \mathrm{M})$ and purified His-tagged RsmE $(165 \mathrm{nM})$ as described in Materials and Methods. The amount of $\left[{ }^{3} \mathrm{H}\right]$-methyl groups incorporated was monitored by acid precipitation and scintillation counting. Data presented are the average of 
on this substrate methylation of U1498 in vitro proceeds very slowly, suggesting that the $30 \mathrm{~S}$ particles are not identical to the true in vivo substrate required by the enzyme.

Based on our data, it is clear that RsmE requires more than free $16 \mathrm{~S}$ rRNA as its minimal substrate, and suggests that it recognizes a specific RNA structure that can only be maintained in the presence of the majority of ribosomal proteins. We also cannot exclude the possibility that RsmE might interact directly with certain ribosomal proteins, as was recently suggested for RsmF (Hallberg et al. 2006).

RsmE is a dimer in solution. It is most active at $100 \mathrm{mM}$ $\mathrm{NH}_{4} \mathrm{Cl}, \mathrm{pH}$ 7-9, and 10-15 $\mathrm{mM} \mathrm{Mg}^{2+}$. The high levels of $\mathrm{NH}_{4}{ }^{+}$are known to stabilize 30S subunit structure (Zamir et al. 1971). More specifically, high $\mathrm{NH}_{4}{ }^{+}$and high $\mathrm{Mg}^{2+}$ conditions were shown to stabilize the $30 \mathrm{~S}$ subunit in an "active" state that is able to support translation. Our data suggest that the "active" state also might be required for $30 \mathrm{~S}$ subunit methylation by RsmE. Thus, the optimal reaction conditions for $\mathrm{RsmE}$ are similar to those for $\mathrm{m}^{5} \mathrm{C} 1407$ methylation by RsmF (Andersen and Douthwaite 2006), but quite different from those for $\mathrm{m}_{2}{ }^{6} \mathrm{~A} 1518$ and $\mathrm{m}_{2}{ }^{6} \mathrm{~A} 1519$ methylation by RsmA (Poldermans et al. 1979). Both RsmA and RsmF require $30 \mathrm{~S}$ particles as substrates, but RsmA is active at low $\mathrm{NH}_{4}{ }^{+}$and intermediate $\mathrm{Mg}^{2+}$ concentrations (Poldermans et al. 1979), conditions in which $30 \mathrm{~S}$ particles are believed to be in an "inactive" state (Zamir et al. 1969). These differences suggest that residues A1518 and A1519 are modified prior to methylation of U1498 or C1407.

Two additional methylated nucleotides, $\mathrm{m}^{4} \mathrm{Cm} 1402$ and $\mathrm{m}^{2} \mathrm{G} 1516$, are present in the $3^{\prime}$ minor domain. No information on the identity of the enzymes involved in their methylation is available, making it difficult to suggest an order of addition for all the methyl groups present in this domain. However, based on the fact that all known methyltransferases that modify nucleotides at the terminal region of $16 \mathrm{~S}$ rRNA prefer highly structured particles, we predict that C1402- and G1516-specific enzymes will also require complex ribonucleoprotein particles as their substrates. The requirement for highly structured substrates also suggests that these enzymes act late during ribosome biogenesis, in agreement with a $5^{\prime}-3^{\prime}$ directed assembly process (Powers et al. 1993; Brodersen et al. 2002).

In this study, we determined the enzymatic properties and the substrate specificity of RsmE. Comparison of its properties with those of other known methyltransferases suggests a possible sequence of methylation events during ribosome biosynthesis. Although the specific roles of methylated nucleotides are not yet known, it is highly probable that ribosomal RNA modification is closely linked with ribosome biogenesis, and it will be important to decipher all the events associated with rRNA modifications in order to completely understand how ribosomes are synthesized, assembled, and maintained in a functionally active state.

\section{MATERIALS AND METHODS}

\begin{abstract}
Materials
$\left[{ }^{3} \mathrm{H}\right]$-S-adenosyl-L-methionine (SAM) was purchased from Amersham Pharmacia Biotech. $\left[\gamma-{ }^{32} \mathrm{P}\right]$ ATP was obtained from PerkinElmer. T4 DNA ligase, T4 polynucleotide kinase, and restriction enzymes were obtained from New England Biolabs. DNase I was obtained from Worthington. Taq DNA polymerase and T7 RNA polymerase were purchased from Promega, and PfuTurbo DNA was obtained from Stratagene. Moloney murine leukemia virus reverse transcriptase (M-MLV-RT) was obtained from Invitrogen. Talon resin was obtained from BD Biosciences.
\end{abstract}

\section{Buffers}

Buffer A contained $50 \mathrm{mM} \mathrm{NaPO}$, pH 7.0, $300 \mathrm{mM} \mathrm{NaCl}$; and buffer B contained $20 \mathrm{mM}$ HEPES, pH 7.5, $60 \mathrm{mM} \mathrm{NH}_{4} \mathrm{Cl}$, $10 \mathrm{mM}$ 2-mercaptoethanol; buffer $\mathrm{C}$ was the same as buffer $\mathrm{B}$, but also contained $300 \mathrm{mM} \mathrm{NH}_{4} \mathrm{Cl}$; buffer D contained $20 \mathrm{mM}$ Tris- $\mathrm{HCl}, \mathrm{pH} 7.8$, and $100 \mathrm{mM} \mathrm{Mg}(\mathrm{OAc})_{2}$; buffer $\mathrm{E}$ was the same as buffer $\mathrm{D}$, but contained $0.1 \mathrm{mM} \mathrm{Mg}(\mathrm{OAc})_{2}$.

\section{Cloning and overexpression of the $m^{3} \mathrm{U}$ methyltransferase gene}

The rsmE gene was amplified by PCR of genomic DNA, using PfuTurbo DNA polymerase, and was cloned into pET28a as described (Basturea et al. 2006). This procedure resulted in isolation of pET28a-rsmE plasmids containing the gene insert fused with an N-terminal His-tag coding region. DNA sequencing showed that the correct gene had been cloned. A nontagged $r s m E$ construct was obtained by ligation of a DNA insert, generated by digestion of the pET28a-rsmE construct with NdeI and XhoI, into pET32a. A pET32a-His-rsmE construct was also obtained by insertion of the DNA fragment generated upon digestion of the pET28a-rsmE with XbaI and XhoI, into pET32a-rsmE digested with the same enzymes. For overexpression, BL21(DE3) cells were transformed with isolated plasmids and grown in LB medium containing $50 \mu \mathrm{g} / \mathrm{mL}$ kanamycin or $100 \mu \mathrm{g} / \mathrm{mL}$ carbenicillin at $37^{\circ} \mathrm{C}$ to an $\mathrm{A}_{600}$ of 0.6 . Isopropyl- $\beta$-D-thiogalactopyranoside (IPTG) at $1 \mathrm{mM}$ was added to the culture, and incubation continued for $2 \mathrm{~h}$. Cells were recovered by centrifugation, washed with Tris buffer-saline (TBS), and stored at $-80^{\circ} \mathrm{C}$.

\section{Gene complementation}

pET32a plasmids containing either the rsmE gene (pET32a-rsmE) or the His-tagged RsmE coding region from pET28a-rsmE (pET32a-His-rsmE) were transformed into MG1655 rsmE::kan. The same strain was also transformed with pHC79-rsmE, constructed as described by Basturea et al. (2006), and with empty pET32a or pHC79 vectors as controls. Transformed cells were grown at $37^{\circ} \mathrm{C}$ to logarithmic phase in $\mathrm{LB}$ medium containing $50 \mu \mathrm{g} / \mathrm{mL}$ kanamycin and $100 \mu \mathrm{g} / \mathrm{mL}$ carbenicillin prior to further analysis.

\section{Primer extension analysis}

Total cellular RNA was extracted as described by Ofengand et al. (2001), and annealed to a $\left[{ }^{32} \mathrm{P}\right] 5^{\prime}$-end-labeled primer specific 
to region $1506-1525$ of $16 \mathrm{~S}$ rRNA. The primer was extended by M-MLV-RT according to the manufacturer's protocol. Primer extension products were precipitated with ethanol, dissolved in DNA loading buffer containing $89 \%$ formamide, $4 \% \mathrm{TE}$ buffer (10 mM Tris-HCl, pH 8.0, 1 mM EDTA), 0.12\% bromophenol blue, and $0.17 \%$ xylene cyanol, separated on $8 \%$ polyacrylamide/7 $\mathrm{M}$ urea sequencing gels, and visualized by exposure to X-ray film.

\section{Protein purification}

His-tagged RsmE was purified by cobalt-immobilized metal affinity chromatography on BD Talon resin, as described (Basturea et al. 2006). Nontagged, recombinant RsmE was purified from BL21(DE3) cells overexpressing the protein. Briefly, cell pellets were thawed on ice using $2 \mathrm{~mL}$ of either buffer $\mathrm{B}$ or buffer $\mathrm{C}$ per $25 \mathrm{~mL}$ of cell culture, and were passed through a French press at 18,000 psi. Cell debris was removed by centrifugation at $16,000 \mathrm{rpm}$ for $20 \mathrm{~min}$ in a SS-34 Sorvall rotor. The supernatant fraction was treated with 2 units of DNase I on ice for $15 \mathrm{~min}$ and centrifuged in a Beckman 60Ti rotor at 32,000 rpm for $4 \mathrm{~h}$ to obtain ribosome-free S100 extracts. The S100 fraction was further fractionated by gel filtration chromatography on a Superose- 6 column. Fractions of $250 \mu \mathrm{L}$ were collected and samples were analyzed by SDS-PAGE. Peak fractions containing RsmE were quickly frozen in a dry-ice/ethanol bath and stored at $-80^{\circ} \mathrm{C}$. Protein concentration was determined from the $\mathrm{A}_{280}$ absorption value and by the Bradford method (Bradford 1976). The absorption coefficient $\left(\varepsilon=13940 \mathrm{M}^{-1} \mathrm{~cm}^{-1}\right)$ was determined based on the number of tryptophan and tyrosine residues according to the Gill and von Hippel (1989) method.

\section{Absorption spectra analysis}

$\mathrm{UV}$ absorption spectra were obtained in buffer $\mathrm{B}$ at $25^{\circ} \mathrm{C}$ with a PerkinElmer Lamda 25 UV/VIS spectrophotometer using a $1-\mathrm{cm}$ quartz cell.

\section{Determination of molecular mass and oligomeric state}

The molecular mass of purified RsmE was determined by gel filtration chromatography using a Superose-6 column (Amersham). The column was calibrated with bovine serum albumin (66.4 $\mathrm{kDa})$, ovalbumin $(43 \mathrm{kDa})$, carbonic anhydrase $(29 \mathrm{kDa})$, and lysozyme $(14 \mathrm{kDa})$. The size of RsmE was determined based on its peak retention volume compared to a standard curve obtained by plotting the log molecular mass versus retention volume for the standard proteins.

\section{Generation and purification of RNA substrates}

70S, 50S, and 30S ribosome particles were purified from MG1655 $\mathrm{I}^{-}$rsmE::kan cells as described by Basturea et al. (2006). 16S rRNA was extracted from mutant $30 \mathrm{~S}$ particles with phenol and chloroform, and precipitated with ethanol. Unmodified 16S rRNA was synthesized in vitro using T7 RNA polymerase transcription of the E. coli 16S rRNA gene present on the pWK1 plasmid (Krzyzosiak et al. 1987). The 16S rRNA 3' terminal region spanning nucleotides 1398-1417 was amplified by PCR with primers 5' - TACCTAATACGACTCACTATAGGGACCGCCCG TCACACCATGGG-3' and 5'-ACCTATGTCTAGACCTAAGG-3' that introduced a $\mathrm{T} 7$ promoter site and a Bsu36I restriction site, respectively. The PCR product was digested with Bsu36I and used as a template for RNA synthesis using the T7 Megashortscript from Ambion.

Partially disassembled ribonucleoprotein particles were obtained by $\mathrm{LiCl}$ treatment of purified, mutant $30 \mathrm{~S}$ particles according to Itoh et al. (1968). Briefly, 30S particles were diluted $\sim 300$-fold in buffer D. The Tris- $\mathrm{HCl}$ concentration was increased to $50 \mathrm{mM}$ and the sample volume was doubled with $100 \mathrm{mM}$ $\mathrm{Mg}(\mathrm{OAc})_{2}$ solution containing $\mathrm{LiCl}$ to give a final concentration of either $0,1 \mathrm{M}, 1.5 \mathrm{M}, 2 \mathrm{M}, 3 \mathrm{M}$, or $3.5 \mathrm{M} \mathrm{LiCl}$. All samples, except the $1 \mathrm{M} \mathrm{LiCl}$, were incubated overnight at $4^{\circ} \mathrm{C}$. The $1 \mathrm{M}$ $\mathrm{LiCl}$ treatment was performed for 1-2 min prior to collection of washed particles by centrifugation at $45,000 \mathrm{rpm}$ in a Beckmann $60 \mathrm{Ti}$ rotor for $6.5 \mathrm{~h}$. The pellets obtained were resuspended in $500 \mu \mathrm{L}$ buffer $\mathrm{E}$ and separated on $10 \%-30 \%$ sucrose gradients by centrifugation in a Beckmann SW28 rotor at 25,000 rpm for 20 h. Peak fractions containing LiCl-washed particles were collected, concentrated by centrifugation through an Amicon Ultra $10 \mathrm{~K}$ cutoff filter, quickly frozen, and stored at $-80^{\circ} \mathrm{C}$.

In vitro reconstitution intermediate particles were obtained from mutant 16S rRNA and total 30S subunit protein (TP30). Purified 30S subunits were precipitated with 20\% PEG-6000 and collected by centrifugation at 20,000 rpm for $15 \mathrm{~min}$ in a Sorvall SS-34 rotor. Pellets were resuspended in buffer B containing $100 \mathrm{mM} \mathrm{NH}_{4} \mathrm{Cl}$ and $10 \mathrm{mM} \mathrm{Mg}(\mathrm{OAc})_{2}$. The $\mathrm{Mg}^{2+}$ concentration was adjusted to $100 \mathrm{mM}$ and the volume was doubled with cold glacial acetic acid. Protein was precipitated with acetone, denatured in buffer $\mathrm{B}$ containing $400 \mathrm{mM} \mathrm{NH}_{4} \mathrm{Cl}, 20 \mathrm{mM}$ $\mathrm{Mg}(\mathrm{OAc})_{2}$, and $6 \mathrm{M}$ urea, and allowed to refold through dialysis against urea free buffer. Each reconstitution reaction contained 16S RNA and equivalent units of TP30 in a 1:2 ratio. One equivalent unit TP30 is defined as the amount of protein required for assembly of a $30 \mathrm{~S}$ particle. The number of equivalent units used in the reaction was determined based on $\mathrm{A}_{230}$ readings such that an $A_{230}$ value of 1 corresponded to eight equivalent units of protein (Denman et al. 1989). Reaction mixtures were incubated at $4^{\circ} \mathrm{C}$ for $1 \mathrm{~h}$, allowed to attain room temperature, and separated on $10 \%-30 \%$ sucrose gradients by centrifugation in a Beckman SW28 rotor at 25,000 rpm for $25 \mathrm{~h}$. Reconstituted intermediate (RI) particles were collected and concentrated by centrifugation through a $10-\mathrm{kDa}$ molecular cutoff filter, quickly frozen in liquid $\mathrm{N}_{2}$ and stored at $-80^{\circ} \mathrm{C}$.

\section{Methyltransferase assays}

Reaction mixtures $(50 \mu \mathrm{L})$ contained $20 \mathrm{mM}$ HEPES, pH 7.0, $100 \mathrm{mM} \mathrm{NH}{ }_{4} \mathrm{Cl}, 5 \mathrm{mM}$ DTT, $100 \mu \mathrm{M}$ SAM, $1 \mu \mathrm{Ci}\left[{ }^{3} \mathrm{H}\right]-\mathrm{SAM}$, $10 \mathrm{mM} \mathrm{Mg}(\mathrm{OAc})_{2}$, substrate, and protein as indicated. Reaction mixtures were incubated for $1 \mathrm{~h}$ at $37^{\circ} \mathrm{C}$, unless otherwise indicated, and the reaction product was precipitated with $2.5 \mathrm{~mL}$ of ice-cold $10 \%$ TCA $/ 2 \%$ casamino-acids solution. Fifty micrograms of salmon sperm DNA were added per reaction to facilitate precipitation. Samples were placed on ice for $10 \mathrm{~min}$ prior to collection on microglass fiber filters (VWR). Filters were washed with $24 \mathrm{~mL}$ of $2.5 \% \mathrm{TCA} / 2 \%$ casamino acids, followed by $5 \mathrm{~mL}$ of $95 \%$ ethanol/diethyl ether (1:1), and allowed to dry. Radioactivity was determined by scintillation counting. 


\section{Determination of kinetic parameters}

Initial reaction rates were determined by varying one substrate concentration at a constant, saturating concentration of the other substrate. Reactions $(50 \mu \mathrm{L})$ contained $165 \mathrm{nM}$ RsmE and the $30 \mathrm{~S}$ subunit concentration was varied from 0.1 to $2 \mu \mathrm{M}$ at $100 \mu \mathrm{M}$ SAM, while the SAM concentration was varied from 5 to $500 \mu \mathrm{M}$ at $2.5 \mu \mathrm{M} 30 \mathrm{~S}$ subunit. Apparent Michaelis-Menten parameters, for both $30 \mathrm{~S}$ particles and SAM, were obtained from double reciprocal plots of three experimental repeats.

\section{ACKNOWLEDGMENTS}

This work was supported by Grant GM58879 from the National Institutes of Health.

Received June 21, 2007; accepted August 3, 2007.

\section{REFERENCES}

Agarwalla, S., Kealey, J.T., Santi, D.V., and Stroud, R.M. 2002. Characterization of the $23 \mathrm{~S}$ ribosomal RNA $\mathrm{m}^{5} \mathrm{U} 1939$ methyltransferase from Escherichia coli. J. Biol. Chem. 277: 8835-8840.

Andersen, N.M. and Douthwaite, S. 2006. YebU is a $\mathrm{m}^{5} \mathrm{C}$ methyltransferase specific for $16 \mathrm{~S}$ rRNA nucleotide 1407. J. Mol. Biol. 3: 777-786.

Badger, J., Sauder, J.M., Adams, J.M., Antonysamy, S., Bain, K., Bergseid, M.G., Buchanan, S.G., Buchanan, M.D., Batiyenko, Y., Christopher, J.A., et al. 2005. Structural analysis of a set of proteins resulting from a bacterial genomics project. Proteins 60: 787-796.

Basturea, G.N., Rudd, K.E., and Deutscher, M.P. 2006. Identification and characterization of RsmE, the founding member of a new RNA base methyltransferase family. RNA 12: 426-434.

Berk, V., Zang, W., Pai, R.D., and Cate, J.H. 2006. Structural basis for mRNA and tRNA positioning on the ribosome. Proc. Natl. Acad. Sci. 103: 15830-15834.

Bradford, M.M. 1976. A rapid and sensitive method for the quantitation of microgram quantities of protein utilizing the principle of protein-dye binding. Anal. Biochem. 72: 248-254.

Brodersen, D.E., Clemons Jr., W.M., Carter, A.P., Wimberly, B.T., and Ramakrishnan, V. 2002. Crystal structure of the 30S ribosomal subunit from Thermus thermophilus: Structure of the proteins and their interactions with 16S RNA. J. Mol. Biol. 316: 725-768.

Culver, G.M. 2003. Assembly of the 30 S ribosomal subunit. Biopolymers 68: 234-249.

Cunningham, P.R., Richard, R.B., Weitzmann, C.J., Nurse, K., and Ofengand, J. 1991. The absence of modified nucleotides affects both in vitro assembly and in vitro function of the $30 \mathrm{~S}$ ribosomal subunit of Escherichia coli. Biochimie 73: 789-796.

Decatur, W.A. and Fournier, M.J. 2002. rRNA modifications and ribosome function. Trends Biochem. Sci. 27: 344-351.

Denman, R., Weitzmann, C., Cunningham, P.R., Nergre, D., Nurse, K., Colgan, J., Pan, Y.C., Miedel, M., and Ofengand, J. 1989. In vitro assembly of $30 \mathrm{~S}$ and $70 \mathrm{~S}$ bacterial ribosomes from 16S RNA containing single base substitutions, insertions, and deletions around the decoding site (C1400). Biochemistry 28: 1002-1011.

Forouhar, F., Shen, J., Xiao, R., Acton, T.B., Montelione, G.T., and Tong, L. 2003. Functional assignment based on structural analysis: Crystal structure of the yggJ protein (HI0303) of Haemophilus influenzae reveals an RNA methyltransferase with a deep trefoil knot. Proteins 53: 329-332.

Gill, S.C. and von Hippel, P.H. 1989. Calculation of protein extinction coefficients from amino acids sequence data. Anal. Biochem. 182: 319-326.
Hager, J., Staker, B.L., Bugl, H., and Jakob, U. 2002. Active site in RrmJ, a heat shock-induced methyltransferase. J. Biol. Chem. 277: 41978-41986.

Hager, J., Staker, B.L., and Jakob, U. 2004. Substrate binding analysis of the 23 S rRNA methyltransferase RrmJ. J. Bacteriol. 186: 66346642.

Hallberg, B.M., Ericsson, U.B., Johnson, K.A., Andersen, N.M., Douthwaite, S., Nordlund, P., Beuscher, A.E., and Erlandsen, H. 2006. The structure of the RNA m5C methyltransferase YebU from Escherichia coli reveals a C-terminal RNA- recruiting PUA domain. J. Mol. Biol. 360: 774-787.

Itoh, T., Otaka, E., and Osawa, S. 1968. Release of ribosomal proteins from Escherichia coli ribosomes with high concentrations of lithium chloride. J. Mol. Biol. 33: 109-122.

Korostelev, A., Trakhanov, S., Laurberg, M., and Noler, H.F. 2006. Crystal structure of a $70 \mathrm{~S}$ ribosome-tRNA complex reveals functional interactions and rearrangements. Cell 126: 1065-1077.

Krzyzosiak, W., Denman, R., Nurse, K., Hellmann, W., Boublik, M., Gehrke, C.W., Agris, T.F., and Ofengand, J. 1987. In vitro synthesis of $16 \mathrm{~S}$ ribosomal RNA containing single base changes and assembly into a functional 30S ribosome. Biochemistry 26: 23532364.

Lesnyak, D.V., Osipiuk, J., Skarina, T., Sergiev, P.V., Bodganov, A.A., Edwards, A., Savchenko, A., Joachimiak, A., and Dontsova, O.A. 2007. Methyltransferase that modifies guanine 966 of the $16 \mathrm{~S}$ rRNA: Functional identification and tertiary structure. J. Biol. Chem. 282: 5880-5887.

Lindhal, L. 1975. Intermediates and time kinetics of the in vivo assembly of Escherichia coli ribosomes. J. Mol. Biol. 92: 15-37.

Maravic, G., Bujnicki, J.M., Feder, M., Pongor, S., and Flögel, M. 2003. Alanine-scanning mutagenesis of the predicted rRNAbinding domain of ErmC' redefines the substrate-binding site and suggests a model for protein-RNA interactions. Nucleic Acids Res. 31: 4941-4949. doi: 10.1093/nar/gkg666.

Ofengand, J. and Del Campo, M. 2004. Modified nucleosides in Escherichia coli ribosomal RNA. In EcoSal-Escherichia coli and Salmonella: Cellular and molecular biology (ed. R. Curtiss). ASM Press, Washington, D.C., www.ecosal.org.

Ofengand, J., Del Campo, M., and Kaya, Y. 2001. Mapping pseudouridines in RNA molecules. Methods 25: 365-373.

Okamoto, S., Tamaru, A., Nakajima, C., Nishimura, K., Tanaka, Y., Tokoyuma, S., Suzuki, Y., and Ochi, K. 2007. Loss of a conserved 7-methylguanosine modification in 16S rRNA confers low-level streptomycin resistance in bacteria. Mol. Microbiol. 63: 1096-1106.

Poldermans, B., Roza, L., and Van Knippenberg, P.H. 1979. Studies on the function of two adjacent N6,N6-dimethyladenosines near the $3^{\prime}$ end of $16 \mathrm{~S}$ ribosomal RNA of Escherichia coli. III. Purification and properties of the methylating enzyme and methylase-30 S interactions. J. Biol. Chem. 254: 9094-9100.

Powers, T., Daubresse, G., and Noller, H.F. 1993. Dynamics of in vitro assembly of $16 \mathrm{~S}$ rRNA into $30 \mathrm{~S}$ ribosomal subunits. J. Mol. Biol. 232: $362-374$.

Schuwirth, B.S., Borovinskaya, M.A., Hau, C.W., Zhang, W., VilaSanjurjo, A., Holton, J.M., and Doundna Cate, J.H. 2005. Structures of the bacterial ribosome at $3.5 \AA$ resolution. Science 310: $827-834$.

Tscherne, J.S., Nurse, K., Popienick, P., Michel, H., Sochacki, M., and Ofengand, J. 1999. Purification, cloning, and characterization of the 16S RNA $\mathrm{m}^{5} \mathrm{C} 967$ methyltransferase from Escherichia coli. Biochemistry 38: 1884-1892.

Yusupov, M.M., Yusupova, A., Baucom, K., Earnest, T.N., Cate, J.H., and Noller, H.F. 2001. Crystal structure of the ribosome at $5.5 \AA$ resolution. Science 292: 883-896.

Zamir, A., Miskin, R., and Elson, D. 1969. Interconversions between inactive and active forms of ribosomal subunits. FEBS Lett. 3: 85-88.

Zamir, A., Miskin, R., and Elson, D. 1971. Inactivation and reactivation of ribosomal subunits: Amino acyl-transfer RNA binding activity of the 30 s subunit of Escherichia coli. J. Mol. Biol. 60: $347-364$. 

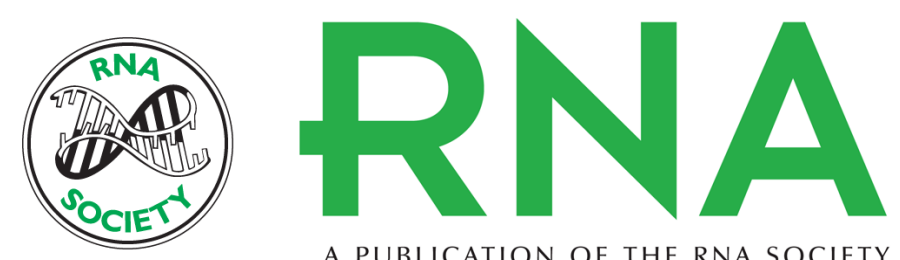

A PUBLICATION OF THE RNA SOCIETY

\section{Substrate specificity and properties of the Escherichia coli 16S rRNA methyltransferase, RsmE}

Georgeta N. Basturea and Murray P. Deutscher

RNA 2007 13: 1969-1976 originally published online September 13, 2007

Access the most recent version at doi:10.1261/rna.700507

References This article cites 31 articles, 9 of which can be accessed free at: http://rnajournal.cshlp.org/content/13/11/1969.full.html\#ref-list-1

License

Email Alerting Receive free email alerts when new articles cite this article - sign up in the box at the Service top right corner of the article or click here. 